\title{
The Isolation of Pleiotropic Mutants of Pseudomonas aminovorans Deficient in the Ability to Grow on Methylamine and an Examination of their Enzymic Constitution
}

\author{
By CHARLES W. BAMFORTH* AND MARY L. O'CONNOR† \\ Department of Microbiology, University of Sheffield, Sheffield S10 2TN
}

(Received 31 July 1978)

\begin{abstract}
Mutants deficient in several enzymes of methylamine oxidation and assimilation have been obtained by treating Pseudomonas aminovorans with ultraviolet light. One of these mutants was studied in detail and was shown to lack the enzymes of trimethylamine and dimethylamine oxidation. In addition, activities of the following enzymes, all postulated as being involved in $\mathrm{C}_{1}$ metabolism, were lost: hydroxypyruvate reductase, serine-glyoxylate aminotransferase, isocitrate lyase, phosphoenolpyruvate carboxylase, $N$-methylglutamate dehydrogenase, $\gamma$-glutamylmethylamide synthetase, formate dehydrogenase and dye-linked formaldehyde dehydrogenase. In contrast, three enzymes - NAD ${ }^{+}$,glutathione-linked formaldehyde dehydrogenase, $N$-methylalanine dehydrogenase and $N$-methylglutamate synthase -- were retained. This phenotype suggests either a lesion in a regulatory gene, a deletion in an early structural gene of an operon or the loss of a plasmid. Results obtained indicated that $P$. aminovorans possesses an isocitrate lyase-serine pathway.
\end{abstract}

\section{INTRODUCTION}

It has been suggested (Jarman \& Large, 1972; Boulton \& Large, 1977) that Pseudomonas aminovorans grows on trimethylamine by the successive oxidation of each of the carbon atoms to formaldehyde by a series of enzymes: trimethylamine monooxygenase (EC 1.14.13.8) (Boulton et al., 1974); trimethylamine $N$-oxide aldolase (EC 4.1.2.-) (Large, 1971); dimethylamine monooxygenase (EC 1.14.99.-) (Eady et al., 1971); $N$-methylglutamate synthase (EC 2.1.1.21) (Jarman, 1973; Bamforth, 1976); and $N$-methylglutamate dehydrogenase (EC 1.5.99.5) (Bamforth \& Large, 1975). The product formaldehyde can then either be further oxidized by means of formaldehyde dehydrogenase and formate dehydrogenase (EC 1.2.1.2) to carbon dioxide (Eady, 1970) or assimilated by the enzymes of the serine pathway (Large \& Carter, 1973). The enzymes of trimethylamine catabolism are induced by transfer to media containing trimethylamine as sole carbon source (Boulton \& Large, 1977), and the serine pathway enzymes are induced by growth on methylamine (Large \& Carter, 1973). It is likely that the enzymes of $C_{1}$ dissimilation and assimilation are coordinately expressed in $P$. aminovorans in a manner comparable to other methylotrophs (Dunstan et al., 1972; O'Connor \& Hanson, 1978).

However, one of the enzymes purported to be involved in the oxidation of methylamine in $P$. aminovorans, $N$-methylglutamate dehydrogenase, has too low a specific activity in cell-free extracts to account for the growth rate of the organism on methylamine (Bamforth

\footnotetext{
* Present address: The Brewing Research Foundation, Lyttel Hall, Nutfield, Redhill, Surrey RH1 4HY.

$\dagger$ Present address: Department of Microbiology, University of Washington, Seattle, Washington 98195 ,
} U.S.A. 
\& Large, 1977). In an attempt to ascertain whether this enzyme was specifically involved in growth on methylamine we tried to isolate mutants of $P$. aminovorans deficient in the ability to grow on methylamine and to ascertain whether these mutants were specifically lacking in $N$-methylglutamate dehydrogenase activity.

We report in this paper the isolation of mutants of $P$. aminovorans which were unable to grow on methylamine, but these were deficient in a number of enzymes which have been postulated as being functionaries in $C_{1}$ metabolism. One of the mutants was studied in detail, with additional investigation of its inability to grow on dimethylamine and trimethylamine hydrochlorides.

Several unanswered and important questions concerning the growth of $P$. aminovorans on methylamine (and other methylamines) are considered. (i) Of what significance is the presence of two separate formaldehyde dehydrogenases in $P$. aminovorans, namely one catalysing an $\mathrm{NAD}^{+}$,gluthathione-dependent reaction (EC 1.2.1.1) and the other dye-linked (EC 1.2.99.-) (Boulton \& Large, 1977)? (ii) Is the low specific activity of isocitrate lyase (Large \& Carter, 1973) specifically due to this enzyme or is it a function of isocitrate dehydrogenase (Attwood \& Harder, 1977)? (iii) Are the enzymes $\gamma$-glutamylmethylamide synthetase (EC 6.3.4.12) (Kung \& Wagner, 1969) and $N$-methylalanine dehydrogenase (EC 1.5.1.-) (Lin \& Wagner, 1975), which have been considered as possible functionaries in the oxidation of methylamine by Pseudomonas MS, of any importance to growth of $P$. aminovorans on $\mathrm{C}_{1}$ substrates?

\section{METHODS}

Organism. Pिseudomonas aminovorans (NCIB 9039) was obtained from Dr P. J. Large, Department of Biochemistry, University of Hull. The organism was maintained and grown as described by Eady et al. (1971).

Preparation of mutant organisms. Mutants unable to grow on methylamine were isolated using ultraviolet light mutagenesis essentially by the method of O'Connor et al. (1977). Ultraviolet light exposure was at a distance of $40 \mathrm{~cm}$ for $2.5 \mathrm{~min}$. Permissive medium contained $0.2 \%(\mathrm{w} / \mathrm{v})$ sodium succinate as carbon source; non-permissive medium contained $0.5 \%(\mathrm{w} / \mathrm{v})$ methylamine hydrochloride as carbon source. Two rounds of penicillin ( 330 units $\mathrm{ml}^{-1}$ ) selection were performed and mutant selection was by replica-plating successively on to methylamine and succinate plates.

Determination of protein. Protein was estimated by the method of Lowry et al. (1951) using dried bovine serum albumin as standard.

Enzyme assays. Enzymes were assayed by unmodified published methods unless otherwise indicated: hydroxypyruvate reductase (EC 1.1.1.29) (Large \& Quayle, 1963) assayed at pH 5.0; serine-glyoxylate aminotransferase (EC 2.6.1.45) (Blackmore \& Quayle, 1970) using an extract of the wild-type organism (14 $\mu \mathrm{g}$ protein) as source of hydroxypyruvate reductase; isocitrate lyase (EC 4.1.3.1) (Dixon \& Kornberg, 1959); phosphoenolpyruvate carboxylase (EC 4.1.1.31) (spectrophotometric method of Large et al., 1962) assayed at pH 7.3 (see Large \& Carter, 1973); trimethylamine monooxygenase (Boulton et al., 1974); trimethylamine $N$-oxide aldolase (Large, 1971) using the method of Chrastil \& Wilson (1975) for formaldehyde estimation; dimethylamine monooxygenase (spectrophotometric method of Eady et al., 1971); Nmethylglutamate synthase (radiochemical assay of Pollock \& Hersh, 1971); $N$-methylglutamate dehydrogenase (Bamforth \& Large, 1977); $N$-methylalanine dehydrogenase (Lin \& Wagner, 1975); dye-linked formaldehyde dehydrogenase (Johnson \& Quayle, 1964); NAD ${ }^{+}$, glutathione-linked formaldehyde dehydrogenase (van Dijken, 1976); formate dehydrogenase (Johnson \& Quayle, 1964); NADP+-linked isocitrate dehydrogenase (Kornberg, 1955).

$\gamma$-Glutamylmethylamide synthetase was assayed essentially as described by Levitch (1977) except that samples of reaction mixture were made alkaline in scintillation vials and dried in a vacuum oven at $25^{\circ} \mathrm{C}$. Liquid scintillator NE213 (5 ml; Nuclear Enterprises, Edinburgh 11) was then added to each vial and radioactivity was counted in an Isocap 300 scintillation counter.

Enzyme units. One milliunit (munit) of enzyme was the amount required to catalyse the formation of $1 \mathrm{nmol}$ product (or the disappearance of 1 nmol substrate) $\min ^{-1}$.

Preparation of cell-free extracts. Wild-type and methylamine-negative organisms were grown in separate 1-litre batches of succinate medium for $24 \mathrm{~h}$, harvested aseptically and resuspended in 1-litre batches of methylamine- or trimethylamine-medium. Cultures were incubated for $48 \mathrm{~h}$ at $30^{\circ} \mathrm{C}$ on a gyratory shaker before harvesting, washing once in distilled water and resuspending in approx. 5 vol. 50 mm-potassium 
phosphate, $\mathrm{pH} 7 \cdot 0$. (For assay of $N$-methylglutamate synthase the extracting buffer was $100 \mathrm{~mm}$-Tris/HCl, pH $8 \cdot 5$, containing $60 \mathrm{~mm}-\mathrm{KCl}, 50 \mathrm{mM}$-L-glutamate, $1 \mathrm{mM}$-EDTA and $50 \mu \mathrm{M}-\mathrm{FMN}$; for assay of $\gamma$-glutamylmethylamide synthetase the extracting buffer was $10 \mathrm{~mm}$-potassium phosphate, $\mathrm{pH} 7 \cdot 0$, containing $1 \mathrm{~mm}$ methylamine hydrochloride, $1 \mathrm{~mm}$-L-glutamate, $1 \mathrm{~mm}-\mathrm{MnCl}_{2}, 0.25 \mathrm{~mm}$-ATP and $1 \mathrm{~mm}$-dithiothreitol.) Bacteria adapted to growth on methylamine were disrupted with an MSE ultrasonic disintegrator (model $150 \mathrm{~W}$ ) at full power for $4 \times 0.5 \mathrm{~min}$ intervals interspersed by cooling in ice. Debris was removed by centrifuging at $10000 \mathrm{~g}$ for $10 \mathrm{~min}$ at $4{ }^{\circ} \mathrm{C}$. Bacteria adapted to growth on trimethylamine were broken by passing once through a French pressure cell, pre-cooled to $0{ }^{\circ} \mathrm{C}$, at $103 \mathrm{MPa}$. Debris was removed as above.

Enzymes other than $N$-methylglutamate dehydrogenase were assayed using the supernatant from crude extracts centrifuged at $100000 \mathrm{~g}$ for $1 \mathrm{~h}$. $\mathrm{N}$-Methylglutamate dehydrogenase activity was estimated in the resulting pellet.

Determination of the product of isocitrate metabolism. The product of isocitrate metabolism was determined by analysis of dinitrophenylhydrazone derivatives as described by Attwood \& Harder (1977).

\section{RESULTS}

\section{Isolation and screening of mutants unable to grow on methylamine}

A large number of mutants unable to grow on methylamine but capable of growth on succinate were isolated. Approximately $75 \%$ of the culture obtained was estimated to be of this phenotype.

Four mutants $\left(\mathrm{M}_{1}, \mathrm{M}_{2}, \mathrm{M}_{4}\right.$ and $\left.\mathrm{M}_{5}\right)$ possessing the above phenotype were selected and obtained in pure culture for detailed study. On permissive substrates the mutants produced a characteristic soluble yellow pigment which was indistinguishable from that produced by the wild-type organism. There were no noticeable morphological differences between the mutant and wild-type species when cells stained with methylene blue were examined microscopically.

Mutant and wild-type organisms were examined for a number of enzymes believed to be involved in growth on methylamine (Anthony, 1975; Loginova \& Trotsenko, 1977) (Table 1). Each of the mutant organisms had lost the activities of serine-glyoxylate aminotransferase, $\mathrm{N}$-methylglutamate dehydrogenase, dye-linked formaldehyde dehydrogenase and formate dehydrogenase. [Although limited by the amount of hydroxypyruvate reductase added by way of wild-type crude extract, sufficient extract was added to allow a rate for a potential serine-glyoxylate aminotransferase reaction of 3.6 munits (mg protein) ${ }^{-1}$.] Mutant $M_{1}$ retained a very much reduced level of hydroxypyruvate reductase, whereas this enzyme was absent from the other mutants. Mutant $\mathrm{M}_{4}$ was the only one to retain phosphoenolpyruvate carboxylase, albeit at a four-fold lower specific activity than the wild-type species. Mutants $\mathrm{M}_{1}$, and to a lesser extent $\mathrm{M}_{2}$, retained isocitrate lyase unlike the other two mutants. All the mutants retained $\mathrm{N}$-methylalanine dehydrogenase and $\mathrm{NAD}^{+}$,glutathione-linked formaldehyde dehydrogenase.

\section{Mutant $\mathrm{M}_{5}$}

Mutant $\mathrm{M}_{5}$ was completely devoid of the enzymes referred to above, and so was selected for further work. It was able to grow on succinate, glucose, pyruvate, glutamate and citrate, in common with the wild-type organism (Bamforth, 1976), but not on methylamine, dimethylamine or trimethylamine. Although ethanol was not a substrate for either the wild-type or $\mathrm{M}_{5}$, acetate supported very weak growth of both strains.

Mutant $M_{5}$ was unable to synthesize $\gamma$-glutamylmethylamide synthetase but retained the ability to produce $N$-methylglutamate synthase (Table 1). Following exposure to trimethylamine the mutant did not produce trimethylamine monooxygenase, trimethylamine $N$-oxide aldolase or dimethylamine monooxygenase, which were detectable in the wild-type at specific activities of $8.3,0.8$ and 5.6 munits (mg protein) ${ }^{-1}$, respectively. These specific activities, in addition to several quoted in Table 1, are low compared with those reported by Large \& Carter (1973) and Boulton \& Large (1977); this difference is probably due to extracts being prepared from cells harvested well into stationary phase of growth. 
Table 1. Enzyme activities in wild-type and mutant strains of P. aminovorans

Cells were grown on succinate medium before harvesting and resuspending in medium containing $0.5 \%$ methylamine hydrochloride as sole carbon source. Cells were harvested and washed after $48 \mathrm{~h}$ and extracts were prepared as described in Methods.

\begin{tabular}{|c|c|c|c|c|c|}
\hline \multirow[b]{2}{*}{ Enzyme } & \multicolumn{5}{|c|}{ Specific activity [munits (mg protein $)^{-1}$ ] } \\
\hline & Wild-type & $\mathrm{M}_{1}$ & $\mathbf{M}_{2}$ & $\mathbf{M}_{4}$ & $\mathbf{M}_{5}$ \\
\hline Hydroxypyruvate reductase & 256 & 32 & 0 & 0 & $0^{*}$ \\
\hline Serine-glyoxylate aminotransferase & $27 \cdot 4$ & 0 & 0 & 0 & 0 \\
\hline Isocitrate lyase & $15 \cdot 3$ & $13 \cdot 6$ & $4 \cdot 7$ & 0 & 0 \\
\hline Phosphoenolpyruvate carboxylase & $32 \cdot 7$ & 0 & 0 & $8 \cdot 1$ & $0 *$ \\
\hline$N$-Methylglutamate synthase & $5 \cdot 4$ & 一 & - & - & $3 \cdot 0$ \\
\hline$N$-Methylglutamate dehydrogenase & $1 \cdot 24$ & 0 & 0 & 0 & 0 \\
\hline$\gamma$-Glutamylmethylamide synthetase & $12 \cdot 3$ & 一 & - & - & 0 \\
\hline$N$-Methylalanine dehydrogenase & $16 \cdot 3$ & $13 \cdot 8$ & $19 \cdot 4$ & $19 \cdot 1$ & $23 \cdot 8$ \\
\hline $\begin{array}{l}\text { Dye-linked formaldehyde } \\
\text { dehydrogenase }\end{array}$ & $1 \cdot 5$ & 0 & 0 & 0 & 0 \\
\hline $\begin{array}{l}\mathrm{NAD}^{+} \text {,glutathione-linked } \\
\text { formaldehyde dehydrogenase }\end{array}$ & 1630 & 1810 & 1150 & 1570 & 1710 \\
\hline Formate dehydrogenase & $3 \cdot 2$ & 0 & 0 & 0 & 0 \\
\hline $\begin{array}{l}\text { NADP }^{+} \text {-linked isocitrate } \\
\text { dehydrogenase }\end{array}$ & $17 \cdot 2$ & 一 & 一 & - & $16 \cdot 5$ \\
\hline
\end{tabular}

0 , Not detected; - , not tested.

* Upon completion of the assay with mutant extract, addition of extract of wild-type organism started the reaction, indicating that the absence of activity in the mutant was not due to an inhibitor in the mutant preparation.

Isocitrate lyase activity was not detected in $\mathrm{M}_{5}$ whereas the enzyme had a specific activity of 15.3 munits (mg protein) $)^{-1}$ in crude extracts of wild-type organism grown on methylamine. The presence of isocitrate dehydrogenase in wild-type and $\mathrm{M}_{5}$ extracts suggests that the measured isocitrate lyase activity is not an artefact caused by the activity of isocitrate dehydrogenase (see Attwood \& Harder, 1977). Glyoxylate was detected as its dinitrophenylhydrazone from analysis of terminated isocitrate lyase reaction mixtures, whereas there was no evidence for the formation of 2-oxoglutarate.

\section{Attempted isolation of revertants of mutant $\mathrm{M}_{5}$}

Attempts using $N$-methyl- $N^{\prime}$-nitro- $N$-nitrosoguanidine to isolate revertants of $\mathrm{M}_{5}$ capable of growth on methylamine were unsuccessful.

\section{DISCUSSION}

We have isolated pleiotropic mutants of $P$. aminovorans unable to metabolize methylamines. These mutants, with the possible exception of $M_{1}$, seem to be fundamentally similar in having lost many of the enzymes which have been postulated as being involved in the oxidation of methylamine and the allied biosynthetic pathways in $P$. aminovorans. Simultaneous loss of several related functions is generally indicative of common regulatory systems for the genes involved. Pleiotropy of this sort in other bacteria has been found to result from deletion, polar nonsense or frameshift mutations in an operon, or from mutations in regulatory genes (Goldberger \& Berberich, 1966; Yanofsky \& Ito, 1966; Cohn \& Monod, 1953). Any of these kinds of mutations could explain the phenotypes of the mutants described here, although the first three require the affected genes to be physically linked. Linkage of some genes for $\mathrm{C}_{1}$-related functions has been reported in the methylotroph Methylobacterium organophilum (O'Connor \& Hanson, 1978), but no linkage data is available for $P$. aminovorans. 
An alternative explanation for the phenotype of mutant $M_{5}$ would be the loss of a plasmid coding for the affected genes. The presence of low but detectable levels of some $C_{1}$ enzymes in mutants $M_{1}, M_{2}$ and $M_{4}$ makes this unlikely unless these mutants contained lesions on the plasmid, while mutant $\mathbf{M}_{5}$ has lost the plasmid completely. Several plasmids coding for catabolic pathway genes have been described in Pseudomonas spp. (Williams \& Worsey, 1976). Further work must centre on attempts to isolate such a structure, as has been done, for example, with $P$. putida (Palchaudhuri \& Chakrabarty, 1976). Bacterial strains have typically been 'cured' of plasmids by treatment with mitomycin C, an inhibitor of DNA synthesis (Iyer \& Szybalski, 1963), and it would be interesting to discover whether the ability to metabolize methylamines could be lost from $P$. aminovorans by treatment with this mutagen.

Loss of a plasmid would account for our lack of success in isolating revertants of the $P$. aminovorans mutants capable of growth on methylamine. Alternative explanations are that the ultraviolet light-induced mutation is either a deletion of a base pair or is due to multiple lesions. The probability of obtaining a mutant with several single lesions is essentially negligible.

The presence of $N$-methylalanine dehydrogenase, $N$-methylglutamate synthase and $\mathrm{NAD}^{+}$,glutathione-linked formaldehyde dehydrogenase activities in the mutants suggests that they are regulated independently from the other enzymes postulated as being involved in $\mathrm{C}_{1}$ metabolism. $\mathrm{N}$-Methylalanine dehydrogenase (Boulton \& Large, 1977) and $\mathrm{N}$ methylglutamate synthase both appear to be constitutive enzymes in $P$. aminovorans and it seems that they may have a more general role in the economy of the cell. It is conceivable that they are functionally related. The demonstration of $\gamma$-glutamylmethylamide synthetase in the wild-type is the first report of this activity in $P$. aminovorans. Both this enzyme and $N$-methylglutamate dehydrogenase are absent from mutant $\mathrm{M}_{5}$. Loginova et al. (1976) reported that when trimethylamine-grown Hyphomicrobium vulgare $\mathrm{ZV}$ was pulsed with $\left[{ }^{14} \mathrm{C}\right]$ methylamine or $\left[{ }^{14} \mathrm{C}\right]$ trimethylamine the label appeared earliest in $\gamma$-glutamylmethylamide, with $N$-methylglutamate being next labelled. They concluded that methylamine entered metabolism via this route with an unidentified enzyme catalysing the interconversion of these compounds. Studies with Hyphomicrobium x supported this conclusion (Meiberg \& Harder, 1978). Whether $\gamma$-glutamylmethylamide and $N$-methylglutamate are intermediates on a common pathway in $P$. aminovorans also, or are separate ports of entry for methylamine into metabolism, is as yet unknown.

From the results of this study, no definite conclusions can be drawn concerning the role of the formaldehyde dehydrogenases present in P. aminovorans (i.e. which is involved in amine metabolism, or whether both take part). However, it would appear that it is the dyelinked activity which is regulated with the other enzymes of $C_{1}$ metabolism suggesting that its role may be specifically linked to growth on $\mathrm{C}_{1}$ compounds. The nicotinamide nucleotidelinked activity may have a less specific role; the latter enzyme certainly seems to be regulated independently from the $\mathrm{C}_{1}$-specific enzymes. Both enzymes are induced during growth of P. aminovorans on trimethylamine (Boulton \& Large, 1977). [It should be noted that the use of non-physiological electron acceptors is unlikely to provide true activity values - this has been discussed previously with regard to $N$-methylglutamate dehydrogenase (Bamforth \& Large, 1977) - and therefore the two formaldehyde dehydrogenases may in fact not be so disproportionate in activity.] The possibility of a plasmid in $P$. aminovorans coding for $\mathrm{C}_{1}$ functions might offer an explanation for the presence of two formaldehyde dehydrogenases in this organism. If methylotrophy in $P$. aminovorans were the result of the receipt of a ' $C_{1}$ plasmid' from an unknown donor, then it is conceivable that the dye-linked formaldehyde dehydrogenase was acquired via this plasmid, and the $\mathrm{NAD}^{+}$,glutathione-linked activity was already present as a chromosomal gene.

The demonstration of glyoxylate but not 2-oxoglutarate as product in the isocitrate lyase reaction mixture seems to confirm that the serine pathway of carbon assimilation in 
$P$. aminovorans is of the icl $^{+}$variety (Large \& Carter, 1973). Quayle (1975) has calculated that a specific activity for isocitrate lyase of 115 munits (mg protein) ${ }^{-1}$ is required to support a $5 \mathrm{~h}$ doubling time for an icl-serine pathway organism. Considering that the doubling time of $P$. aminovorans growing on methylamine is about $6 \mathrm{~h}$ (Bamforth \& Large, 1977) our reported activities are low, as were those of Large \& Carter (1973).

In view of the apparent loss of phosphoenolpyruvate carboxylase activity in mutant $M_{5}$, its ability to grow using glucose and pyruvate as carbon sources raises the question of the nature of the anaplerotic enzyme(s) replenishing the tricarboxylic acid cycle. It will be interesting to investigate whether $P$. aminovorans can synthesize two different phosphoenolpyruvate carboxylase enzymes as in Pseudomonas ma (Newaz \& Hersh, 1975).

We wish to thank Professor J. R. Quayle for kindly providing facilities and encouragement for this study. M. L. O'C. was the recipient of a Leverhulme Postdoctoral Fellowship.

\section{REFERENCES}

Anthony, C. (1975). The biochemistry of methylotrophic microorganisms. Science Progress, Oxford 62, 167-206.

Attwood, M. M. \& Harder, W. (1977). Isocitrate lyase activity in Hyphomicrobium spp.: a critical reappraisal. FEMS Microbiology Letters 1, 25-30.

BAMFORTH, C. W. (1976). The solubilization and properties of $N$-methylglutamate dehydrogenase from Pseudomonas aminovorans and its role during growth on methylamine. Ph.D. thesis, University of Hull.

Bamforth, C. W. \& Large, P. J. (1975). Solubilization and partial purification of $N$-methylglutamate dehydrogenase from Pseudomonas aminovorans. Biochemical Society Transactions 3, 10661069.

Bamforth, C. W. \& LARge, P. J. (1977). Solubilization, partial purification and properties of $N$ methylglutamate dehydrogenase from Pseudomonas aminovorans. Biochemical Journal 161, 357-370.

Blackmore, M. A. \& Quayle, J. R. (1970). Microbial growth on oxalate by a route not involving glyoxylate carboligase. Biochemical Journal 118, 53-59.

Boulton, C. A. \& Large, P. J. (1977). Synthesis of certain assimilatory and dissimilatory enzymes during bacterial adaptation to growth on trimethylamine. Journal of General Microbiology 101, 151-156.

Boulton, C. A., Crabie, M. J. C. \& Large, P. J. (1974). Microbial oxidation of amines. Partial purification of a trimethylamine mono-oxygenase from Pseudomonas aminovorans and its role in growth on trimethylamine. Biochemical Journal 140, 253-263.

Chrastil, J. \& Wilson, J. T. (1975). A sensitive colorimetric method for formaldehyde. Analytical Biochemistry 63, 202-207.

COHN, M. \& Monod, J. (1953). Specific inhibition and induction of enzyme synthesis. Symposia of the Society for General Microbiology 3, 132-140.

VAN DIJKEN, J. P. (1976). Oxidation of methanol by yeast. $\mathrm{Ph} . \mathrm{D}$. thesis, University of Groningen, The Netherlands.
Dixon, G. H. \& Kornberg, H. L. (1959). Assay methods for key enzymes of the glyoxylate cycle. Biochemical Journal 72, 3P.

Dunstan, P. M., Anthony, C. \& Drabble, W. T. (1972). Microbial metabolism of $C_{1}$ and $C_{2}$ compounds. The role of glyoxylate, glycollate and acetate in the growth of Pseudomonas AMI on ethanol and $\mathrm{C}_{1}$ compounds. Biochemical Journal 128, 107-115.

EADY, R. R. (1970). The bacterial oxidation of mono- and dimethylamines. Ph.D. thesis, University of Hull.

EADY, R. R., JARMAN, T. R. \& LARGE, P. J. (1971). Microbial oxidation of amines. Partial purification of a mixed function secondary amine oxidase system from Pseudomonas aminovorans that contains an enzymically active cytochrome- $P-420$ type haemoprotein. Biochemical Journal 125, 449-459.

Goldberger, R. R. \& Berberich, M. A. (1966). Studies on the mechanism of derepression of the histidine operon in $S$. typhimurium. Federation Proceedings 25, 337-338.

IYER, V. N. \& SzYBALSKI, W. (1963). A molecular mechanism of mitomycin action: linking of complementary DNA strands. Proceedings of National Academy of Sciences of the United States of America 50, 355-362.

JARMAN, T. R. (1973). The enzymic oxidation of primary and secondary amines by Pseudomonas aminovorans. Ph.D. thesis, University of Hull.

JARMan, T. R. \& LARGe, P. J. (1972). Distribution of the enzymes oxidizing secondary and tertiary amines in Pseudomonas aminovorans grown on various substrates. Journal of General Microbiology 73, 205--208.

Johnson, P. A. \& QuAyle, J. R. (1964). Microbial growth on $C_{1}$ compounds. 6 . Oxidation of methanol, formaldehyde and formate by methanol-grown Pseudomonas AM1. Biochemical Journal 93, 281-290.

KORNBERG, A. (1955). Isocitric dehydrogenase of yeast (NADP ${ }^{+}$. Methods in Enzymology 1, 705-707.

KUNG, H. F. \& WAGNER, C. (1969). $\gamma$-Glutamyl- 
methylamide. A new intermediate in the metabolism of methylamine. Journal of Biological Chemistry 244, 4136-4140.

LARGE, P. J. (1971). Non-oxidative demethylation of trimethylamine $N$-oxide by Pseudomonas aminovorans. FEBS Letters 18, 297-300.

LARGe, P. J. \& Carter, R. H. (1973). Specific activities of enzymes of the serine pathway of carbon assimilation in Pseudomonas aminovorans and Pseudomonas ms grown on methylamine. Biochemical Society Transactions 1, 1291-1293.

Large, P. J. \& Quayle, J. R. (1963). Microbial growth on $\mathrm{C}_{1}$ compounds. 5. Enzyme activities in extracts of Pseudomonas Am1. Biochemical Jolirnal 87, 386-396.

Large, P. J., Peel, D. \& Quayle, J. R. (1962). Microbial growth on $\mathrm{C}_{1}$ compounds. 4. Carboxylation of phosphoenolpyruvate in methanolgrown Pseudomonas AM1. Biochemical Journal 85, 243-250.

Levitch, M. E. (1977). An assay for the enzymatic synthesis of $\gamma$-glutamylmethylamide. Analytical Biochemistry 82, 463-467.

Lin, M. C. M. \& Wagner, C. (1975). Purification and characterization of $N$-methylalanine dehydrogenase. Journal of Biological Chemistry 250, 3746-3751.

Loginova, N. V. \& Trotsenko, Y. A. (1977). The metabolic pathways of methylated amines in bacteria. Abstracts of the International Symposium on Microbial Growth on $C_{1}$ Compounds, Puschino, pp. 37-39.

Loginova, N. V., Shishkina, V. N. \& Trotsenko, Y. A. (1976). Primary metabolic pathways of methylated amines in Hyphomicrobium vulgare. Microbiology (English trans. of Mikrobiologiya) 45, 34-40.

Lowry, O. H.. Rosebrough, N. J., Farr, A. L. \& Randall, R. J. (1951). Protein measurement with the Folin phenol reagent. Journal of Biological Chemistry 193, 265-275.
Meiberg, J. B. M. \& Harder, W. (1978). Aerobic and anaerobic metabolism of trimethylamine, dimethylamine and methylamine in Hyphomicrobium x. Journal of General Microbiology 106, 265-276.

Newaz, S. S. \& Hersh, L. B. (1975). Reduced nicotinamide adenine dinucleotide-activated phosphoenolpyruvate carboxylase in Pseudomonas MA: potential regulation between carbon assimilation and energy production. Journal of Bacteriology 124, 825-833.

O'Connor, M. L. \& HANSON, R. S. (1978). Linkage relationships between mutants of Methylobacterium organophilum impaired in their ability to grow on one-carbon compounds. Journal of General Microbiology 104, 105-111.

O'Connor, M. L., Wopat, A. E. \& Hanson, R. S. (1977). Genetic transformation in Methylobacterium organophilum. Journal of General Microbiology 98, 265-272.

Palchaudhuri, S. \& Chakrabarty, A. (1976). Isolation of plasmid deoxyribonucleic acid from Pseudomonas putida. Journal of Bacteriology 126, 410-416.

Pollock, R. J. \& Hersh, L. B. (1971). N-Methylglutamate synthetase. Purification and properties of the enzyme. Journal of Biological Chemistry 246, 4737-4743.

QuAYLE, J. R. (1975). Unsolved problems in the microbial metabolism of methane and methanol. Microbial Growth on $C_{1}$ Compounds, Proceedings of the International Symposium, Tokyo, pp. 59-65.

Williams, P. A. \& WorseY, M. J. (1976). Plasmids and catabolism. Biochemical Society Transactions 4, 466-468.

YANOFSKy, C. \& ITo, J. (1966). Nonsense codons and polarity on the tryptophan operon. Journal of Molecular Biology 21, 313-323. 